\title{
How does temperature affect functional kleptoplasty? Comparing populations of the solar-powered sister-species Elysia timida Risso, 1818 and Elysia cornigera Nuttall, 1989 (Gastropoda: Sacoglossa)
}

\author{
Elise Marie Jerschabek Laetz ${ }^{1,2^{*}}$ and Heike Wägele ${ }^{1}$
}

\begin{abstract}
Background: Despite widespread interest in solar-powered sea slugs (Sacoglossa: Gastropoda), relatively little is know about how they actually perform functional kleptoplasty. Sister-taxa Elysia timida and E. cornigera provide an ideal model system for investigating this phenomenon, since they feed on the same algal genus and only E. timida is capable of long-term kleptoplasty. Recent research has explored factors regarding functional kleptoplasty in E. timida, including their starvation longevity, digestive activity, autophagal response and photosynthetic efficiency under two different temperature conditions $\left(18^{\circ} \mathrm{C}\right.$ and $21^{\circ} \mathrm{C}$ ). These studies revealed the trends E. timida displays regarding each factor during starvation as well as influences temperature has on some aspects of functional kleptoplasty. This study examines $E$. cornigera regarding each of these factors in an attempt to elucidate differences between each species that could explain their differing kleptoplastic abilities. Since both species naturally occur in $25^{\circ} \mathrm{C}$ seawater (E. timida peak summer temperature, E. cornigera low winter temperature), each species was acclimatized to $25^{\circ} \mathrm{C}$ to facilitate comparison and determine if these species exhibit physiological differences to starvation when under the same environmental conditions.
\end{abstract}

Results: When comparing the different E. timida temperature treatments, it becomes clear that increased temperatures compromise E. timida's kleptoplastic abilities. Specimens acclimatized to $25{ }^{\circ} \mathrm{C}$ revealed shorter starvation longevities surviving an average 42.4 days compared to the 95.9 day average observed in specimens exposed to $18^{\circ} \mathrm{C}$. Each temperature treatment displayed a significantly different decrease throughout the starvation period in both, the rate of photosynthetic efficiency and in the decreasing functional kleptoplast abundance. Lysosomal abundances are assessed here as indicators of different aspects of metabolic activity, which could be correlated to temperature. E. cornigera, also acclimatized to $25^{\circ} \mathrm{C}$ did not display significantly similar patterns as any of the E. timida temperature treatments, having fewer incorporated kleptoplasts, a higher lysosomal response to starvation, a faster decrease in photosynthetic efficiency and a lower starvation longevity.

Conclusions: These results confirm that each species has different physiological reactions to starvation and kleptoplast retention, even under the same conditions. While temperature affects aspects of functional kleptoplasty, it is likely not responsible for the differences in kleptoplastic abilities seen in these species.

Keywords: Kleptoplasty, Elysia, Intracellular digestion, Endosymbiosis, Sacoglossa

\footnotetext{
* Correspondence: melaetz@gmail.com

'Zoological Research Museum Alexander Koenig, 160 Adenauerallee, 53113 Bonn, Germany

${ }^{2}$ Institute for Evolutionary Biology and Ecology, University of Bonn, An der Immenburg 1, 53121 Bonn, Germany
}

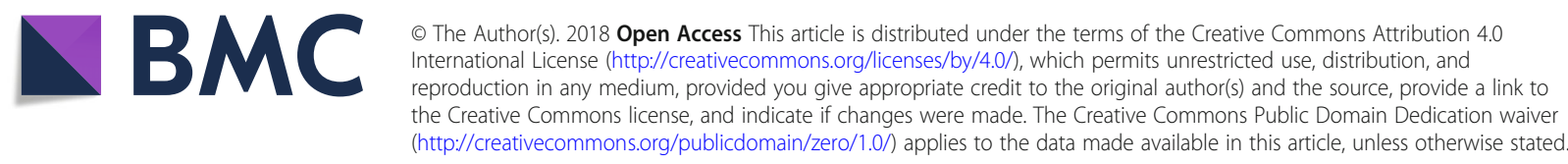




\section{Background}

Some members of the enigmatic sea slug clade, Sacoglossa (Gastropoda: Heterobranchia) are the only known metazoan taxa capable of enslaving functional chloroplasts from their algal food in a process entitled functional kleptoplasty [1-5]. Elysia timida Risso, 1818 has long been used as a model organism in investigations regarding functional kleptoplasty due to the extended period they can remain alive without access to food (averaging about 90 days) and their widespread distribution in high densities across the Mediterranean Sea [6-16]. The high functionality of their sequestered chloroplasts and the duration these kleptoplasts remain active, as revealed by Pulse Amplitude Modulated Fluorometry (PAM) data, groups E. timida with a few other species as a Long-term (plastid) Retaining - LtR species $[7,17-22]$.

LtR species are found throughout the world's temperate and tropical oceans. E. chlorotica is probably the most well-known sacoglossan slug and holds the record for chloroplast retention with up to 14 months, depending on the report [17, 23-28]. This stenophagous slug, feeding only on Vaucheria litorea Agardh, 1873, is found on the western Atlantic coast, between Nova Scotia, Canada and Florida, USA [25]. Plakobranchus ocellatus Hasselt, 1824 is found throughout the Indo-Pacific where it feeds on numerous food algae and can survive starvation for up to 10 months, [23, 29-31]. E. crispata Mörch, 1863 and E. clarki Pierce, Curtis, Massey, Bass, Karl \& Finney, 2006, currently debated as to whether they are two distinct species or one species with two morphotypes living in different ecosystems, are found in the Caribbean where they eat a multitude of algal species and last up to 40 days in starvation [17, 21, 22, 32-34]. The limapontioidean species Costasiella ocellifera (Simroth, 1895) also survives over 50 days [19]. E. viridis has been attributed to the LtR group, however reports on its starvation longevity and photosynthetic efficiency vary, leading some to remove it from this group [35-40]. Another species, E. asbecki Wägele, Stemmer, Burghardt, Händeler, 2010 may also retain functional kleptoplasts for extended durations, however this is only suggested due to PAM activity in the first few weeks of starvation and requires confirmation before it can be considered a LtR form [41].

Recent phylogenetic analyses have confirmed $E$. timida and E. cornigera Nutall, 1989 as sister-species $[17,33,34,42,43]$. These organisms are anatomically very similar, and were even synonymized as one species [44] before the name $E$. cornigera was resurrected and reassigned to the Caribbean populations, limiting E. timida to the Eastern Atlantic and Mediterranean Sea populations [42]. Although they are again considered separate species, E. timida and E. cornigera occur in similar habitats coastal lagoons and the sublittoral zone at $0-10 \mathrm{~m}$ depth. Both species feed by sucking the cell contents out of
Acetabularia sp. (Dasyclades: Chlorophyta) cells: E. timida feeds on the Mediterranean algal species A. acetabulum Silva, 1952, while E. cornigera feeds on Caribbean Acetabularia species [33]. Despite not encountering it in the field, E. cornigera is capable of feeding on A. acetabulum and has not been reported to have a diminished longevity when the food is switched $[8,45]$. Interest in $E$. timida and $E$. cornigera as a model system is beginning to gain a foothold because $E$. cornigera cannot withstand the extended starvation periods $E$. timida can $[45,46]$. While E. timida has a slow decline in photosynthetic efficiency throughout its long starvation period, E. cornigera kleptoplasts also begin high in efficiency, but then drop rapidly as the animal starves, leading to their classification as a Shortterm Retaining (StR) form [33].

Populations of E. timida and E. cornigera have been recorded living in a range of differing types of habitats. Two previously recorded habitats for both species comprise coastal lagoons, characterized by highly fluctuating abiotic factors such as light, temperature and salinity $[15,42]$ and shallow sea areas, which provide a more stable environment, having less abiotic factor fluctuation due to depth and the consistent influx of new seawater. Despite the relative stability of shallow sea areas in contrast to lagoons, abiotic factors in shallow sea Mediterranean areas differ significantly from those in the Caribbean. Mediterranean salinity is higher with an average 37.838.6 practical salinity units (psu) in Blanes, Spain, whereas Caribbean seawater averages 35.5-36.5 psu (NOAA). E. cornigera is also naturally found in warmer waters than $E$. timida: the Caribbean surface temperature along the Florida Keys ranges between 25 and $30{ }^{\circ} \mathrm{C}$ each year [47], while the Mediterranean ranges from 14 to $25{ }^{\circ} \mathrm{C}$ at Blanes, Spain [48]. The range in temperatures E. timida naturally experiences has already been shown to influence a number of factors related to functional kleptoplasty [8]. Despite both species naturally occurring at $25{ }^{\circ} \mathrm{C}$ in shallow sea areas, these species have never been investigated under the same conditions with regard to functional kleptoplasty and their ability to withstand extended starvation.

Digestive activity and starch production in E. timida have been previously assessed for two different populations, each of which displayed significantly different results [37, 49]. A spring population was kept in a warmer environment (20$22{ }^{\circ} \mathrm{C}$ ) reflecting the surface temperature where they were collected, while the fall population was collected and cultured at $18{ }^{\circ} \mathrm{C}$ matching the temperature from which they were collected. The trends observed in each of these investigations were the same, but the time frames differed, with the warmer population showing increases in digestive activity, starch maxima and death occurring earlier in the starvation period. This revealed that temperature may be responsible for this shift and that its effects warrant further study [49]. Additionally, the increased 
temperatures and photosynthetic rates almost align with published E. cornigera data, leading us to hypothesize that the lower temperatures naturally experienced by E. timida may facilitate long-term plastid retention and a long survival duration in starvation.

In this study, the following factors were compared in order to elucidate differences between these species and determine which factors are influenced by temperature: longevity in starvation, photosynthetic efficiency (PAM), functional kleptoplast abundance, digestive activity (lysosome activity within the digestive gland), autophagy (lysosomal activity outside the digestive gland) and excrement content for E. cornigera and E. timida. This is the first report to examine functional kleptoplast abundance, digestive activity, and excrement content for E. cornigera. E. timida specimens were compared under three temperature regimes reflecting natural conditions $\left(18{ }^{\circ} \mathrm{C}, 21{ }^{\circ} \mathrm{C}\right.$, and $25{ }^{\circ} \mathrm{C}$ ) to elucidate the effect temperature has on metabolic processes regarding functional kleptoplasty in this species. Furthermore, the $25{ }^{\circ} \mathrm{C} \mathrm{E}$. timida population reflects natural conditions this species experiences and mirrors those experienced by E. cornigera, which allows the direct comparison of these species. Our working hypothesis therefore is, that E. timida and E. cornigera will display significant differences for each of the factors examined here despite experiencing the same environmental conditions, which supports the idea that each species has physiological differences regarding functional kleptoplasty and starvation. To exclude the effects of irradiance - which varies highly in each natural environment, both species were placed under the same artificial lighting conditions. $E$. cornigera were also transitioned to A. acetabulum to avoid any effects of the algal species.

\section{Methods}

\section{Field collection and lab conditions}

Four aquaria containing lab-cultured Acetabularia acetabulum were transferred from an $18{ }^{\circ} \mathrm{C}$ culture room to a $22{ }^{\circ} \mathrm{C}$ room in March, 2016. This culture was established using specimens collected the previous year. The temperature was slowly increased using tank heaters until it reached $25^{\circ} \mathrm{C}$. Two of these tanks were gradually introduced to water with a lower salinity to match that of the Caribbean Sea: 36.5 psu seawater (from Mediterranean average 37.8-38.6 psu (NOAA). This was done to ensure that the algae consumed by E. cornigera did not suffer any effects of a sudden change in salinity.

Adult Elysia cornigera $(n=50)$ were collected on Spanish Harbor Key (approximately 24ㅇ․ $64^{\prime} 97.83^{\prime \prime} \mathrm{N}, 81^{\circ} 31^{\prime} 67.57^{\prime \prime} \mathrm{W}$ ) in April, 2016. They were removed from rocks covered in Acetabularia crenulata at a depth of $0.3-1 \mathrm{~m}$. The surface water temperature was $25{ }^{\circ} \mathrm{C}$. Animals were relocated to Bonn, Germany for experimentation. In Bonn, they were first acclimatized to artificial seawater and a $12 \mathrm{~h} \mathrm{~L}: 12 \mathrm{~h} \mathrm{D}$ artificial light cycle $\left(220 \mu \mathrm{mol}\right.$ quanta $\left.\mathrm{m}^{-2} \mathrm{~s}^{-1}\right)$ for a week. They were then transitioned to the food alga $A$. acetabulum (previously acclimatized to $25{ }^{\circ} \mathrm{C}$ ) and allowed a further three acclimatization weeks to ensure most if not all of their sequestered chloroplasts derived from $A$. acetabulum rather than $A$. crenulata.

Adult E. timida $(n=40)$ were collected in July, 2016 in Blanes, Spain on rocks covered in A. acetabulum at 3$7 \mathrm{~m}$ depth. The water temperature was $23.3{ }^{\circ} \mathrm{C}$ when measured (measured at $7 \mathrm{~m}$ depth, surface temperature $24.2{ }^{\circ} \mathrm{C}$ ). Animals were transported to Bonn, Germany and acclimatized to laboratory conditions for a week. Artificial lighting provided $220 \mu \mathrm{mol}$ quanta $\mathrm{m}^{-2} \mathrm{~s}^{-1}$ light for $12 \mathrm{~h} \mathrm{~L}: 12 \mathrm{~h}$ D. Large tanks $(50-90 \mathrm{~L})$ containing 25 specimens and abundant food algae were then slowly warmed to $25^{\circ} \mathrm{C}$ over the course of a week, by placing the tank in a $22{ }^{\circ} \mathrm{C}$ room and using tank heaters. They were then given a week to feed and acclimatize to the higher temperature before experimentation began. To better reflect the natural acclimatization to a broader range of temperatures, data already available from specimens in the same wild population (Blanes, Spain) are included here [37]. These animals were collected during fall and spring seasons and kept according to their actual and natural acclimatization at $18{ }^{\circ} \mathrm{C}$ and $21{ }^{\circ} \mathrm{C}$ respectively, in the same room, same tanks, under the same light regimes as the $25{ }^{\circ} \mathrm{C} \mathrm{E}$. timida (summer population) and E. cornigera populations.

E. cornigera were not subjected to multiple temperature treatments for multiple reasons including such as: our investigation set out to examine these species under natural conditions and E. cornigera has not been reported from water colder than $\sim 24{ }^{\circ} \mathrm{C}$ (Fig. 1; 2) subjecting E. cornigera to temperatures lower than those which they are naturally adapted could have a variety of different effects and would not reflect the natural conditions in which they are found and to which they are adapted; 3) collection limits necessitated prioritizing a limited number of animals for each experiment and prohibited studying artificially induced colder temperatures.

\section{Laboratory procedures}

The sample time points chosen for E. timida $25^{\circ} \mathrm{C}$ were $0,7,14,21,30,42$ days in starvation, to match the time points from the fall and spring season surveyed in Laetz et al. [37]. Sixty and 89 days were planned but the slugs did not survive past 42 days. E. cornigera were sampled at $0,7,14,21$ days. Ten specimens of each species were placed in $25{ }^{\circ} \mathrm{C}$ aquaria and each specimen's starvation longevity was recorded. For both E. timida and E. cornigera, three Pulse Amplitude Modulated Fluorometry (PAM) measurements were taken for nine specimens, after $15 \mathrm{~min}$ of dark acclimatization, for each time point, according to the protocol established by Wägele and Johnsen [18]. Pulse 


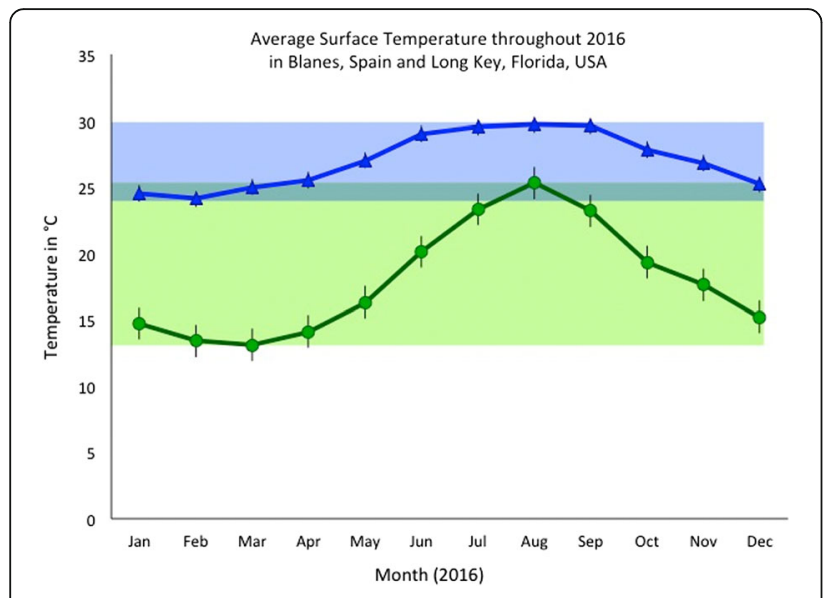

Fig. 1 The average sea surface temperature in Blanes, Spain and Spanish Harbor Key, Florida, USA for 2016 according to satellite maps provided by NOAA. The monthly average for Blanes, Spain is depicted with a green line and the range is shaded in green showing E. timida's natural temperature range. E. cornigera's natural temperature range is shown by blue shading and the blue line depicts the monthly average temperature. The overlap in these ranges occurs at $25^{\circ} \mathrm{C}$ and is depicted by bluish-green shading

Amplitude Modulated fluorometry (PAM) is a technique that allows the calculation of values, which reflect the overall photosynthetic efficiency of chloroplasts within a tissue (maximum quantum yield of photosystem II). These values are expressed as a percentage (the relative value $\mathrm{F}_{\mathrm{V}} / \mathrm{F}_{\mathrm{M}}$ ).
For the following experiments, three specimens from each species were used per time point and per temperature treatment although extra individuals were also included in case they were needed (E. timida used in experiment: $n=$ 24; E. cornigera used in experiments: $n=12$ ). They were photographed (Fig. 2) and stained by placing each specimen in a $5 \mu \mathrm{mol}$ acridine orange and filtered seawater solution for $30 \mathrm{~min}$ [37]. They were then vivisected and placed on a microscope slide for confocal microscopy on a Leica SPE Confocal Laser Scanning Microscope (CLSM). Five different cross-sections were scanned to gather an impression of the digestive activity throughout the entire animal. Each scan was $8 \mu \mathrm{m}$ deep, encompassing the entire thickness of the digestive gland tubule wall cells, while avoiding digestive gland lumen and tissue outside the digestive gland. Acridine Orange is excited by the blue laser $(488 \mathrm{~nm})$ and emits photons at 645-670 $\mathrm{nm}$ (dimer type optimum $656 \mathrm{~nm}$ ) in extremely acidic environments such as lysosomes. Functional chloroplast abundance was also measured during these scans, by capturing chlorophyll a autofluorescence with blue laser excitation $(488 \mathrm{~nm})$ and 600-640 $\mathrm{nm}$ as the accepted emission range (chlorophyll optimum $633 \mathrm{~nm}$ ) [37].

\section{Excrement surveys}

Throughout the experimental processes, E. timida and E. cornigera were kept in tanks of 25 animals, without access to food. Weekly cleaning inhibited the growth of
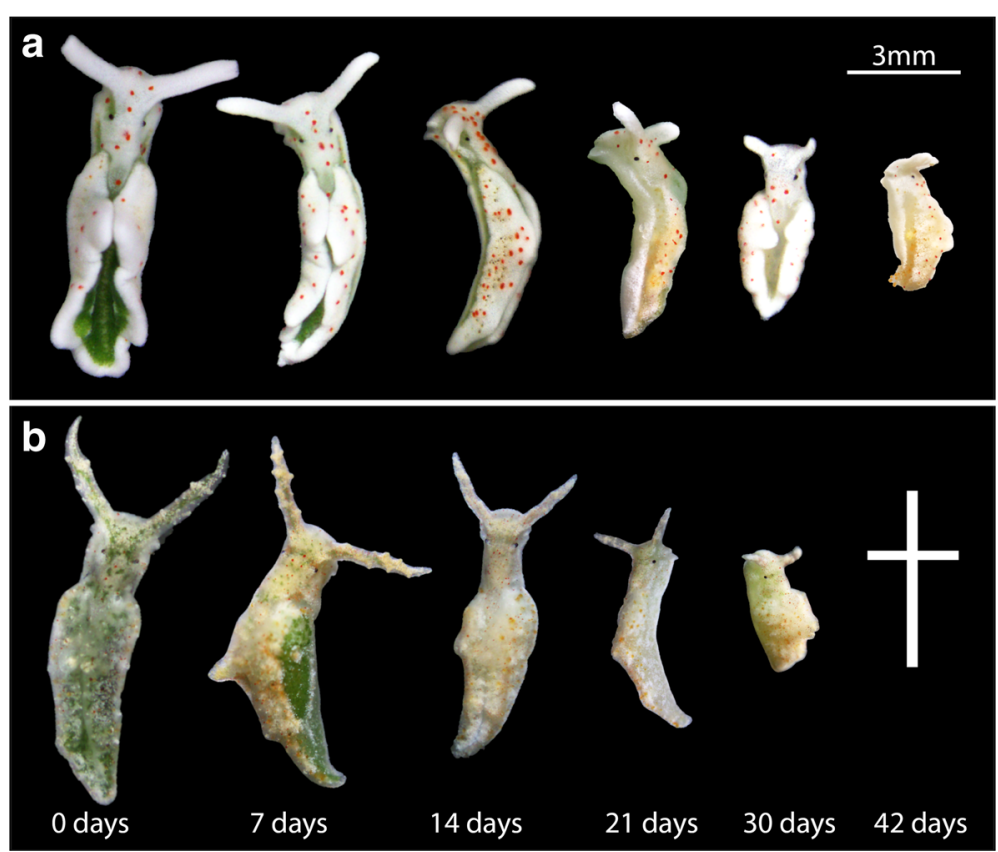

Fig. 2 Species investigated during starvation. a $E$. timida during starvation at $25^{\circ} \mathrm{C}$. The loss of green pigmentation is due to the loss of chlorophyll a within the slug. b E. cornigera during starvation. The cross ( $\dagger$ ) at the end of the E. cornigera series indicates that this species did not survive starvation up to 42 days 
algae in these tanks. Excrement samples from each tank were examined weekly to determine if chloroplasts were present, indicating the decreases in functional chloroplast abundance is due to excretion rather than digestion. This was accomplished using the CLSM to look for chlorophyll a autofluorescence in intact chloroplasts for each of the excrement samples.

\section{Statistical analyses}

PAM values $(n=9)$ and starvation longevities $(n=10)$ were compared using QQ plots to assess normality and populations best modeled by linear functions with an $\mathrm{r}^{2}$ value $>0.90$ were considered normally distributed. Levene's test was applied to assess homogeneity of variance once normality was established. When the assumptions for a one-way standard ANOVA were met, this test was used to ascertain if differences in the recorded values were significant for each time point. Tukey HSD post hoc testing was used to compare amongst the individual treatments when the ANOVA proved significant. For treatments where standard ANOVA assumptions were not met (heterogeneous variances), a Welch ANOVA and subsequent post hoc Games-Howell tests were used instead. The result form each analysis can be found in Additional file 1. Functional chloroplast abundance, lysosome abundance and excrement samples were not statistically analyzed since the number of replicates was too low $(n=3)$.

\section{Results}

\section{Starvation times}

Three E. timida temperature conditions are compared here $(n=10 /$ treatment), to determine if any differences in survival rate are likely due to temperature. Elysia timida starved at $25{ }^{\circ} \mathrm{C}$ survived for a mean $42.4 \pm 3$. 37 days, E. timida $21{ }^{\circ} \mathrm{C}$ withstood $43.3 \pm 2.91$ days, $E$. timida $18{ }^{\circ} \mathrm{C}$ survived $95.90 \pm 3.84$ days, while E. cornigera survived a mean $29.4 \pm 1.78$ days. Each population was assessed with a QQ Plot revealing a strong indication of normally distributed data (as indicated by a linear best-fit model and an $r^{2}$ value $>0.90$ ). Levene's testing for homogeneity of variance was not significant $(p=0.23)$ suggesting homogeneous variances across each group. One-way ANOVA and Tukey HSD analyses reveal a significant difference in the duration starving E. timida (all populations $p<0.01$ ) can withstand as compared here to E. cornigera. Within the E. timida temperature treatments, E. timida $18^{\circ} \mathrm{C}$ survived significantly longer than both E. timida $21{ }^{\circ} \mathrm{C}(p<0.01)$ and E. timida $25^{\circ} \mathrm{C}$ $(p<0.01)$ although E. timida $21{ }^{\circ} \mathrm{C}$ and E. timida $25{ }^{\circ} \mathrm{C}$ did not display significantly differing starvation longevities $(p=0.53)$. The results from each statistical test can be seen in Additional file 1.

\section{Photosynthetic efficiency}

QQ plots for each treatment at each point during starvation allowed the assumption of normally distributed data except for E. cornigera starved for 30 days. This nonnormality is likely due the high frequency of zeros found in the dataset and a lack of equipment sensitivity for very low values. Levene's test for each time point displayed heterogeneity of variance after the control, 0 days in starvation time point. Therefore, Welch ANOVAs were conducted for all of the subsequent comparisons.

Each E. timida temperature treatment, $18{ }^{\circ} \mathrm{C}, 21{ }^{\circ} \mathrm{C}$ and $25{ }^{\circ} \mathrm{C}$, and E. cornigera begin their starvation periods with high PAM values $\left(\mathrm{F}_{\mathrm{V}} \mathrm{F}_{\mathrm{M}}\right)$, having averages of $0.749,0.73,0.765$, and 0.728 respectively. No significant difference was recorded amongst these treatments $(p=0$. 08 ). After only 7 days however, the E. timida populations group significantly with high PAM values: $0.723\left(18{ }^{\circ} \mathrm{C}\right)$, $0.721\left(21{ }^{\circ} \mathrm{C}\right)$ and $0.760\left(25^{\circ} \mathrm{C}\right)(p<0.17)$, while E. cornigera diverges, dropping rapidly to a mean $0.401(p<0.01)$. While each of the E. timida treatments and E. cornigera decrease, the rate of PAM value decrease differs. Welch ANOVAs reveal that after the 0-day time point, E. cornigera PAM values are always significantly lower than each of the E. timida treatments. PAM averages throughout their starvation periods for each of the species examined are summarized in Fig. 3a and the results from each statistical test can be seen in the Additional file 1 .

\section{Functional kleptoplast abundance}

Kleptoplast abundance was also recorded for each time point during the starvation period for each E. timida temperature treatment and E. cornigera. While both species decline in the number of functional chloroplasts, the number of incorporated plastids at the beginning of the starvation period and rates at which they decrease differ (Fig. 3b). E. cornigera has the lowest functional chloroplast retention time and some specimens died with some functional kleptoplasts in their bodies after 21 days (Fig. 4a, h). Both $18{ }^{\circ} \mathrm{C}$ and $21{ }^{\circ} \mathrm{C}$ E. timida populations contained functional chloroplasts until 42 days, while the warmer $E$. timida $\left(25^{\circ} \mathrm{C}\right)$ lost almost all functional chloroplasts earlier, after only 30 days (Fig. 4j, q). An overview of chloroplast decrease in $25^{\circ} \mathrm{C} \mathrm{E}$. timida and E. cornigera can be seen in Fig. 4. Minuscule amounts of chlorophyll a were found in E. timida $18{ }^{\circ} \mathrm{C}$ until 60 days, however the amounts measured are so low they are likely remnants found in degraded thylakoids.

\section{Lysosomal activity}

Lysosomal activity inside the digestive gland tubules is presumably involved in digestion, and used here as an indication of digestive activity in these animals. Each of the E. timida populations surveyed here followed the same trend, a very low lysosomal abundance at the beginning of 

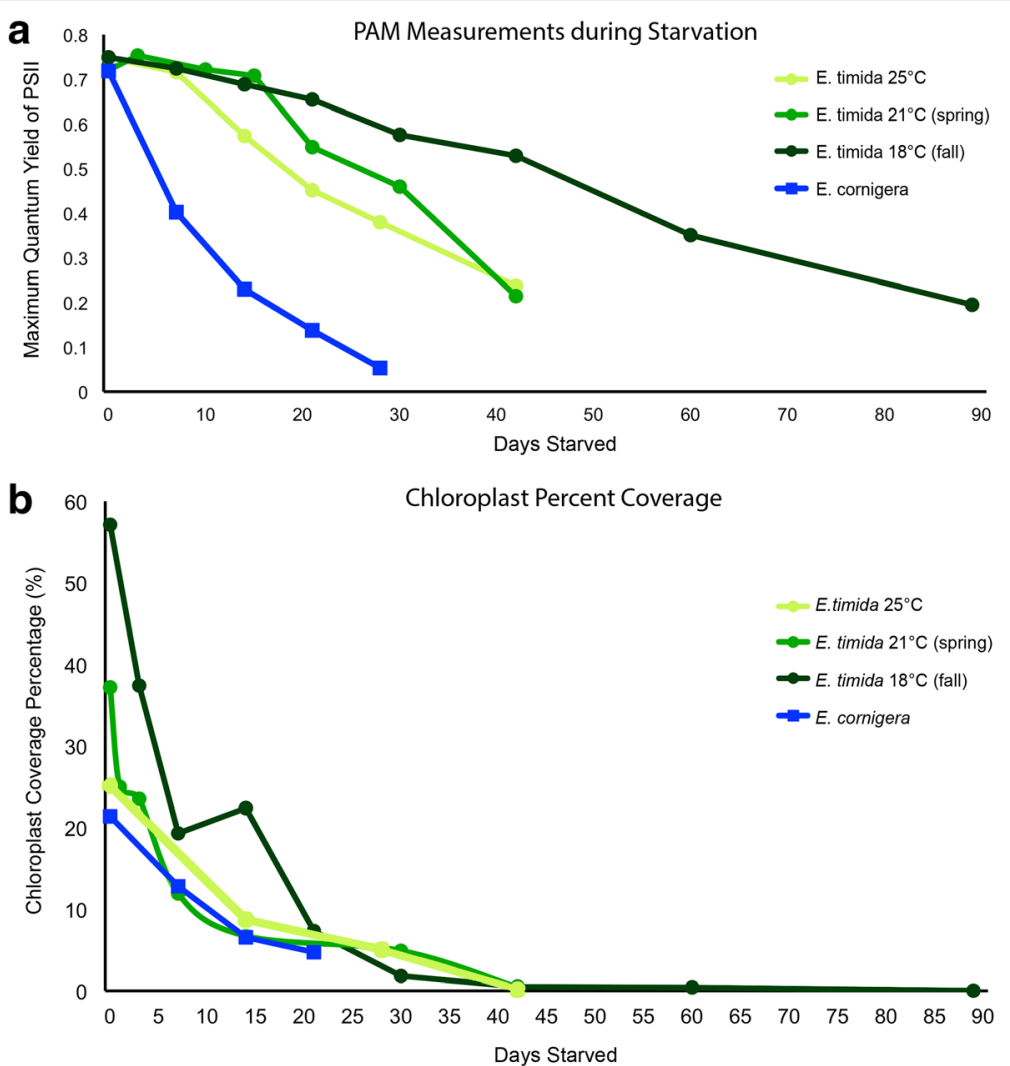

Fig. 3 Functional chloroplast efficiency and abundance. a The chloroplast efficiencies (PAM values) of E. timida in each temperature treatment and $E$. cornigera. E. cornigera drops in photosynthetic efficiency more rapidly than any of the E. timida treatments. Each point is the average of three independent measurements following dark acclimation. E. timida at $25^{\circ} \mathrm{C}$ is denoted by light green circles, at $21^{\circ} \mathrm{C}$ by medium green circles and at $18{ }^{\circ} \mathrm{C}$ by dark green circles. E. cornigera at $25^{\circ} \mathrm{C}$ is represented by blue squares. Lines connecting each point display the average rate of decrease. $\mathbf{b}$ Percent chlorophyll coverage throughout starvation for each examined species. This was computed by measuring the area (in each image, for each stack) that was covered in Digestive Gland Tubule (DGT) and the remaining area - designated as Non-Digestive Gland Tissue. The area covered by functional chloroplasts inside the DGT was divided by the total DGT producing a relative value, a percent of the DGT that is filled with chloroplasts. This value was averaged for each measurement taken (8 images/stack, $5 \mathrm{stacks} / \mathrm{specimen,} 3$ specimens/time point totaling 120 measurements for species at each time point) and graphed here to show the overall trend for each species at each time point. $E$. timida $18{ }^{\circ} \mathrm{C}$ is shown by dark green circles, $21^{\circ} \mathrm{C}$ by medium green circles and $25^{\circ} \mathrm{C}$ by light green circles. E. cornigera is depicted by blue squares. Error bars are not depicted here for graph clarity and can be found in the text

the starvation period $(0-5 \pm 0.22 \%$ of the digestive gland total area covered by lysosomes) and a large increase (48$60 \pm 3.4 \%$ total lysosome coverage) in the second half of the starvation period (differing time spans depending on the temperature acclimatized population) (Fig. $4 \mathrm{j}$ and $5 \mathrm{a}$ ). The averages presented here are the mean lysosome abundance values based on three specimens per time point (15 measurements/specimen). These populations differ however, in the rate of lysosomal increase. $25{ }^{\circ} \mathrm{C} \mathrm{E}$. timida have an almost linear increase, modeled best by the function: $\mathrm{y}=1.16 \mathrm{x}-0.51\left(\mathrm{r}^{2}=0.99\right)$. The $18{ }^{\circ} \mathrm{C}$ and $21{ }^{\circ} \mathrm{C} \mathrm{E}$. timida relative abundances do not increase linearly, instead modeled best by the quadratic functions: $y=0$. $0054 x^{2}+0.23 x+0.99\left(r^{2}=0.99\right)$ and $y=0.052 \times{ }^{2-} 1.07 x$ $+3.69\left(r^{2}=0.95\right)$. The E. cornigera specimens examined display a slight increase in lysosome coverage, from 3.9-9. $4 \pm 1.1 \%$ over the 21 days they starved (Fig. $5 \mathrm{a}$ ).
While lysosomes are an integral part of normal cellular machinery, activity increases above the baseline normal background level, outside the digestive gland, may be indicative of autophagy. Only E. cornigera had changes in the relative percent coverage of lysosomes outside the digestive gland. E. cornigera began the starvation period with a $1.5 \pm 0.31 \%$ non-digestive gland tubule percent coverage, and increased to $4.7 \pm 1.1 \%$ during the 21 -day starvation period. The different E. timida populations displayed minor fluctuations in their percent coverage $(0-0.5 \pm 0.02 \%)$, but never increased to even $1 \%$ percent throughout the entire starvation period (Fig. 5b).

\section{Excrement}

Excrement samples were examined to determine whether or not functional chloroplasts were being excreted throughout the starvation period. Excreted chloroplasts were discovered 


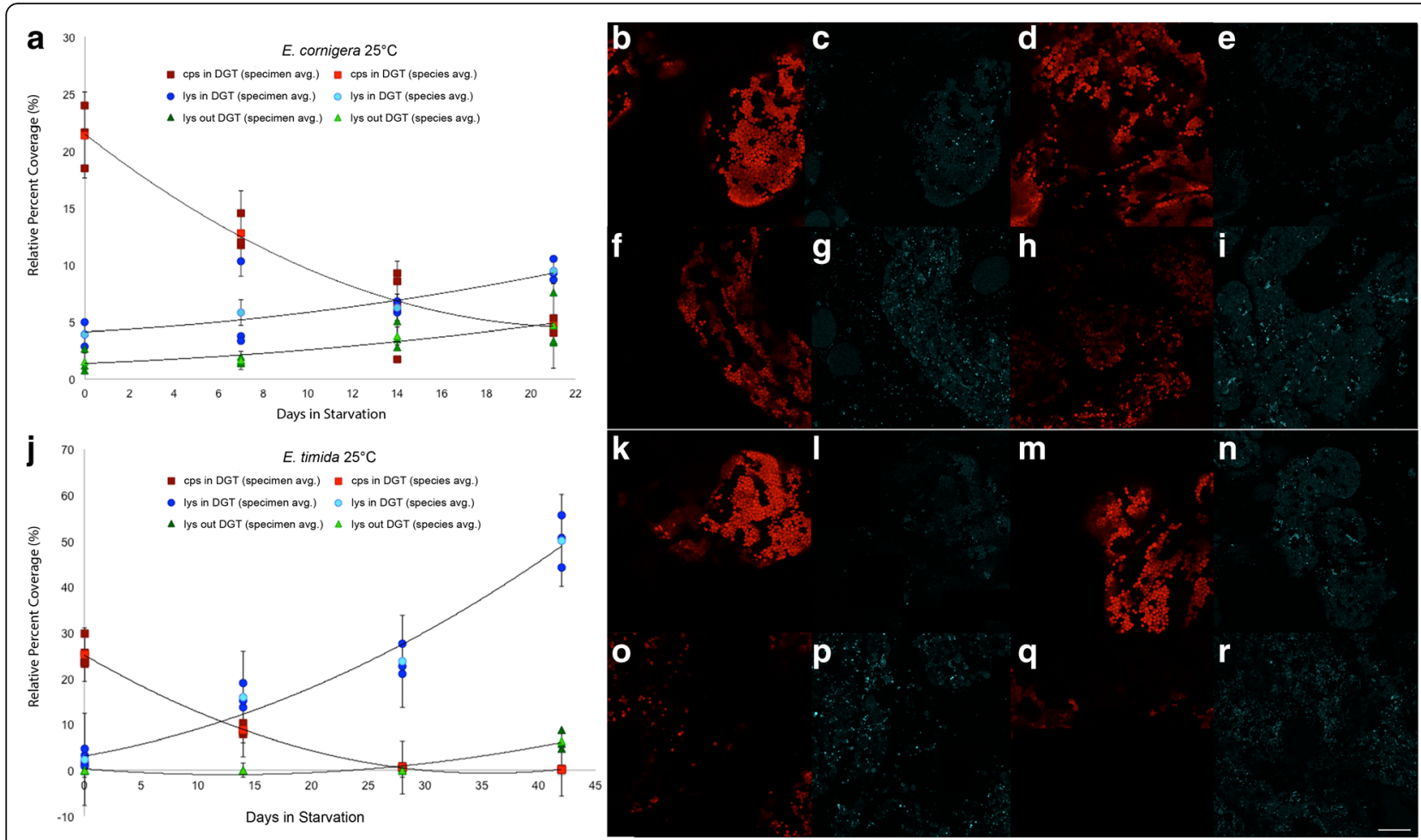

Fig. 4 Functional chloroplast (cps) and lysosome abundance (lys) in E. cornigera and E. timida $25^{\circ} \mathrm{C}$. a-i E. cornigera. j-r E. timida. Functional chloroplasts are depicted by red squares, the dark red ones showing the average per specimen $(n=3)$ and the light red squares showing the average of these three specimens representing the species average at each time point. Lysosomes within the digestive gland tubules (DGT) are illustrated with blue circles, the dark circles again showing the specimen average and the light circles revealing the species average. Lysosomes outside the DGT are demonstrated by green triangles, the dark depicting the specimen average and the light green indicating the species averages. For clarity, error bars (standard error) are only shown for the species average. $\mathbf{b}$ E. cornigera cp abundance at 0-days starved. Cps are falsely colored red. $\mathbf{c}$ E. cornigera lys abundance at 0-days starved. Lys are falsely colored blue. d, e $E$. cornigera - 7-days starved. f, $\mathbf{g} E$. cornigera 14-days starved. $\mathbf{h}$, i E. cornigera - 21-days starved. $\mathbf{j} \mathrm{Cp}$ and lys abundance in E. timida starved at $25^{\circ} \mathrm{C}$. Functional cps and lys in/out DGT are depicted as described above for (a). $\mathbf{k}$ Cps in E. timida $25^{\circ} \mathrm{C}$ starved for 0 days. I Lys in E. timida $25^{\circ} \mathrm{C}$ starved for 0 days. $\mathbf{m}, \mathbf{n} E$. timida $25^{\circ} \mathrm{C}-$ 14 days starved. O, $\mathbf{p}$ E. timida $25^{\circ} \mathrm{C}-21$ days starved. q, r E. timida $25^{\circ} \mathrm{C}-42$ days starved. Error bars are not depicted here for graph clarity and can be found in the text. Scale bar - $50 \mu \mathrm{m}$

in E. cornigera samples throughout the starvation period although chloroplasts were never observed in samples from any of the E. timida populations (Fig. 6a, b). Excreted plastids were still round in shape, appearing intact. Nothing about the chloroplasts found in the E. cornigera excrement appeared different from those found within the slug, except for the debris surrounding them (Fig. 6a).

\section{Discussion}

The duration each $E$. timida treatment from this shallow sea population could survive depends on the temperature conditions to which it was acclimatized. Both E. timida treatments that experienced elevated temperatures $\left(21^{\circ} \mathrm{C}\right.$ and $25^{\circ} \mathrm{C}$ ), lived for a significantly shorter time span, only reaching 42-50 days, while $E$. timida at $18{ }^{\circ} \mathrm{C}$, the temperature recorded in their natural habitat during the fall, survived over 100 days (maximum from this study: 102 days). Interestingly, E. timida at $21{ }^{\circ} \mathrm{C}$ do not survive longer than those at $25^{\circ} \mathrm{C}$. Despite this, temperature may still explain the reported discrepancies for E. timida longevity in starvation, chloroplast abundance, starch abundance and photosynthetic efficiency $[37,49]$. E. cornigera only survived a maximum of 32 days in the laboratory, suggesting that elevated temperatures shorten $E$. timida's life expectancy, but not to the same degree that $E$. cornigera naturally experiences. This indicates that lower temperatures may facilitate E. timida's long-term survival but temperature is not the only factor distinguishing these species from one another regarding longevity in starvation.

The photosynthetic efficiencies of $E$. cornigera and $E$. timida have been reported in previous investigations, and while water temperatures were often reported, these experiments were conducted under a variety of different conditions (different field sites, lab setups, collection times) so comparison to our study risks unintended error $[6,8,17,50]$. In this study, PAM values are recorded for E. timida acclimatized naturally according to environmental temperatures and then accordingly 

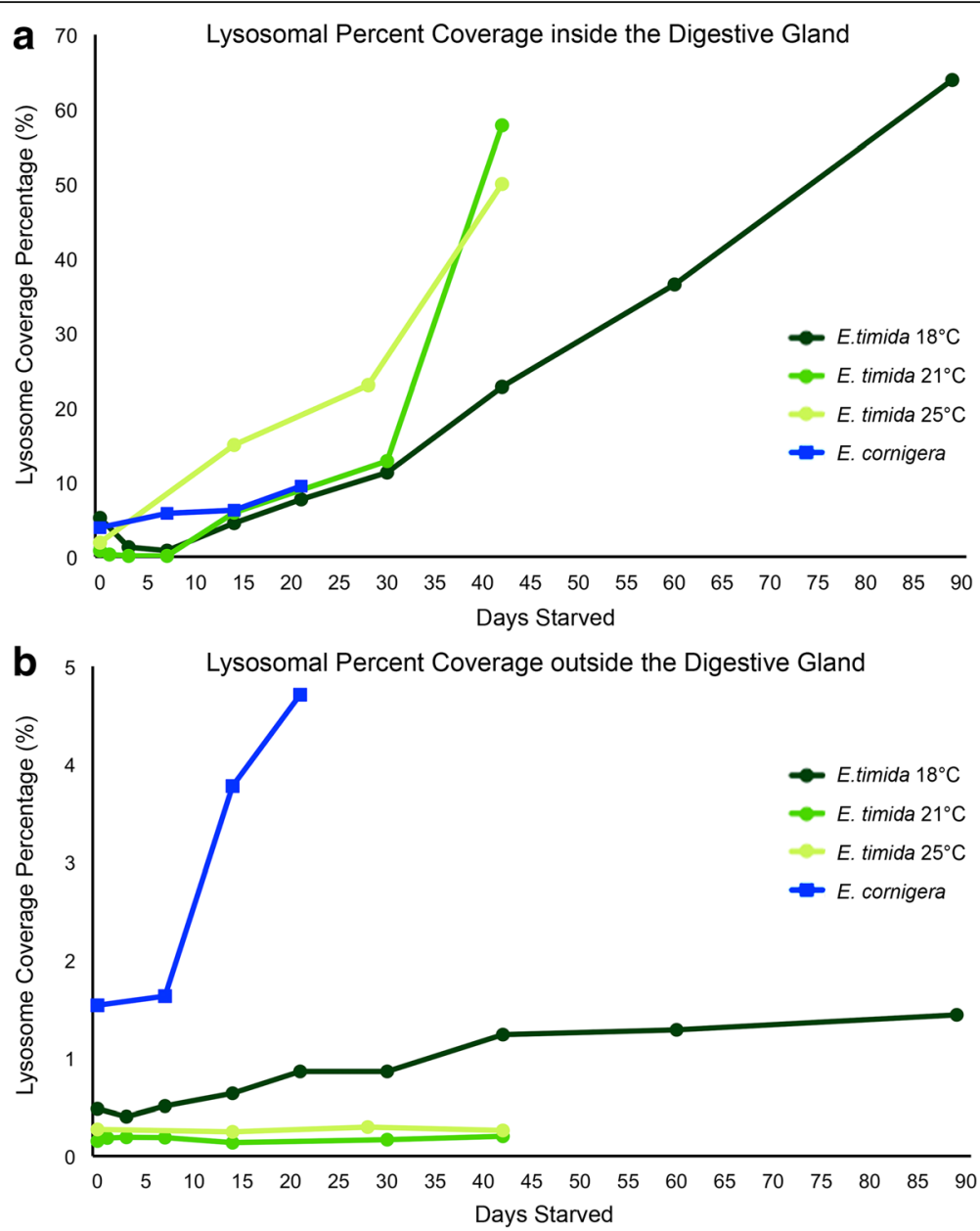

Fig. 5 Lysosome abundance examined throughout a starvation period. a Percent Lysosome Coverage inside the Digestive Gland Tubule (DGT). b Percent Lysosome Coverage outside the DGT. The data in (a and $\mathbf{b})$ were computed following the same procedure as described in Fig. 3 for functional chloroplasts. E. timida $18{ }^{\circ} \mathrm{C}$ is shown by dark green circles, $21^{\circ} \mathrm{C}$ by medium green circles and $25^{\circ} \mathrm{C}$ by light green circles. E. cornigera is depicted by blue squares. Error bars are not depicted here for graph clarity and the values can be found in the text
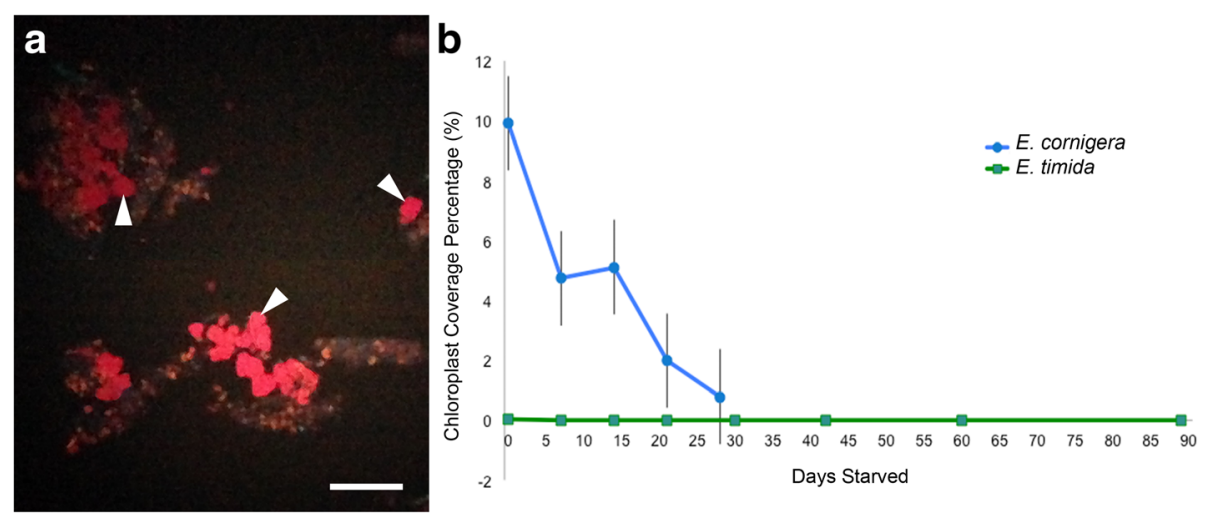

Fig. 6 Functional chloroplasts in E. timida and E. cornigera excrement. a E. cornigera excrement containing a high density of functional kleptoplasts (red circles, a few indicated by arrowheads). b Functional chloroplast density within E. timida and E. cornigera excrement. Since $E$. timida at each temperature treatment lacked chloroplasts in their excrement, they were all graphed as a single $E$. timida line (green squares). The excreted plastid abundance in E. cornigera is depicted by blue circles 
cultivated at $18{ }^{\circ} \mathrm{C}, 21{ }^{\circ} \mathrm{C}$ and $25{ }^{\circ} \mathrm{C}$ and E. cornigera at $25{ }^{\circ} \mathrm{C}$ under standardized conditions. Each E. timida temperature group and the E. cornigera began with a statistically similar value but diverged rapidly, suggesting both $E$. timida and E. cornigera that are fed the same food algae and kept under the same conditions will sequester chloroplasts with the same photosynthetic efficiencies; however once starvation begins, the photosynthetic efficiencies change depending on the temperature and species. Since algae from the same culture was provided each species and the algae for $25^{\circ} \mathrm{C}$ E. timida and E. cornigera was also acclimatized to $25{ }^{\circ} \mathrm{C}$, the differing declines in photosynthetic efficiency between $25^{\circ} \mathrm{C}$ E. timida and $E$. cornigera indicate a difference in the way chloroplasts function and survive in the digestive gland cells of these two species. This suggests the slug species itself is at least partially responsible for the health and longevity of the chloroplasts within its digestive gland and the ability of a chloroplast to be retained is not solely due the algal species involved.

The declines in E. timida photosynthetic efficiency presented in this study differ from the photosynthetic efficiencies measured by Schmitt et al. [8], which also examined E. timida under different temperature regimes. In that study, the temperatures were not closely controlled (fluctuating between $\sim 19-24{ }^{\circ} \mathrm{C}$ depending on the season), and this may explain why their populations did not reveal distinct grouping based on the temperature as they did in this study. Despite the lack of a standardized temperature, both of these studies confirm that higher temperatures lead to a faster decline in photosynthetic efficiency during starvation.

Functional kleptoplast abundance within the digestive gland tissue of multiple species has now been analyzed [37, 51-53]. This analysis adds $E$. cornigera and $E$. timida starved at $25{ }^{\circ} \mathrm{C}$ to determine if there are differences in chloroplast metabolism inherent to the slugs' cells that are independent to the natural temperatures these animals encounter and the results here indicate this to be the case. Each of the treatments investigated here reveal a different rate of functional chloroplast decrease, with no two treatments sharing a similar rate, although they all decrease. Despite consuming the same algal species and living in side-by-side aquaria under the same lab conditions (light, temperature...), E. timida $25{ }^{\circ} \mathrm{C}$ and $E$. cornigera do not display the same decrease in functional chloroplasts. E. cornigera were even observed dying with functional chloroplasts inside their digestive gland tubules, while none of the E. timida temperature treatments were observed containing functional plastids at their time of death. The only discernable abiotic factor that was different in each tank was the salinity of the water, which was always matched to the natural conditions each species encounters in the field. The effects of salinity on functional kleptoplasty require further investigation to determine whether or not it influences chloroplast vitality.

Two other kleptoplast retaining species, Thuridilla hopei (StR) and Elysia viridis (StR or LtR depending on the ingested algae) have been investigated regarding digestive activity, kleptoplast abundance and the potential autophagal response [37]. Despite confirmation that both species are StR forms, T. hopei and E. cornigera do not display the same pattern regarding functional chloroplast abundance in their tissues. They survive about the same time in starvation, however $T$. hopei is devoid of functional chloroplasts after only 14 days (confirming observations made by Martin et al. [54]) whereas E. cornigera dies with some functional chloroplasts still incorporated. E. viridis, which is sometimes considered a StR species also differs in functional chloroplast abundance, having no sign of functional chloroplasts by the end of its starvation period, but lasting an average of 10 days longer in starvation. E. viridis is enigmatic however, having various starvation longevities that may depend on the algae ingested, and exhibiting various photosynthetic efficiencies in starvation, so further research is required to facilitate a proper comparison to this species [35, 40, 54].

Two of the E. timida populations $\left(21{ }^{\circ} \mathrm{C}\right.$ and $\left.25{ }^{\circ} \mathrm{C}\right)$ showed a faster decline in the number of functional chloroplasts, lower number of sequestered plastids at the beginning of the starvation period and faster death by starvation, however they still survived starvation longer than E. cornigera (this study), E. viridis and T. hopei [37]. A comparison of all of the E. timida populations here also shows that temperature does not seem to affect the rate of functional chloroplast decrease in the tissues, since $25{ }^{\circ} \mathrm{C}$ E. timida have a higher rate of decrease than the $21{ }^{\circ} \mathrm{C}$ and $18{ }^{\circ} \mathrm{C}$ groups. While $18{ }^{\circ} \mathrm{C} \mathrm{E}$. timida lived the longest, their functional plastid abundance was almost non-existent after 42 days, the same time span observed in $21{ }^{\circ} \mathrm{C}$ E. timida and $25{ }^{\circ} \mathrm{C}$ E. timida. These results seem to contradict results that show the maximum amylose concentration inside kleptoplasts occurring at 42 days in $18{ }^{\circ} \mathrm{C}$ starved E. timida, which also indicates the presence of these plastids since amylose is accumulated within the plastid [49]. However, this discrepancy is likely due to the means by which kleptoplast abundance/presence was assessed. Upon examining histological sections, it is clear that kleptoplasts are still present until after 63 days [49], however if they do not contain structurally intact chlorophyll a, they will not be detected using chlorophyll a autofluorescence. This highlights the need for a method that accurately quantifies kleptoplast abundance in these slugs and does not rely on autofluorescence.

Lysosomal activity within the digestive gland tubule network was monitored as an indicator of digestive activity in these tissues. Two different patterns were observed amongst the species examined. Species with low longevities 
in starvation, E. cornigera, E. viridis and T. hopei, display a steady increase in lysosomal abundance during their starvation periods [37]. E. timida, however, can withstand a much longer duration without food and exhibits a two part pattern: the first half of the starvation period is marked by a slight increase in the number of lysosomes while the second half of the starvation period reveals a faster rate and significantly higher lysosome abundance. This pattern occurs within each of the temperature treatments investigated here suggesting temperature and lysosome production are not correlated in this species.

Lysosomal activity outside the digestive system is not involved in an organisms digesting foreign material as food, but rather comprises an organism's internal digestion of its own cellular components as part of normal cellular functioning and as autophagy. There was no observable difference between E. timida at $18{ }^{\circ} \mathrm{C}$ and $21{ }^{\circ} \mathrm{C}$ when compared to $E$. timida $25^{\circ} \mathrm{C}$ and these populations closely resembled those observed for E. viridis [37]. Neither $E$. cornigera nor $T$. hopei displayed a trend that aligned with E. timida or E. viridis, indicating each of these species has a different autophagal responses during starvation. The strong increase in lysosomes produced by $E$. cornigera and T. hopei after 7 days in starvation suggests an activation of autophagal procedures in these animals. This furthers conclusions made by de Vries et al. [45] when they

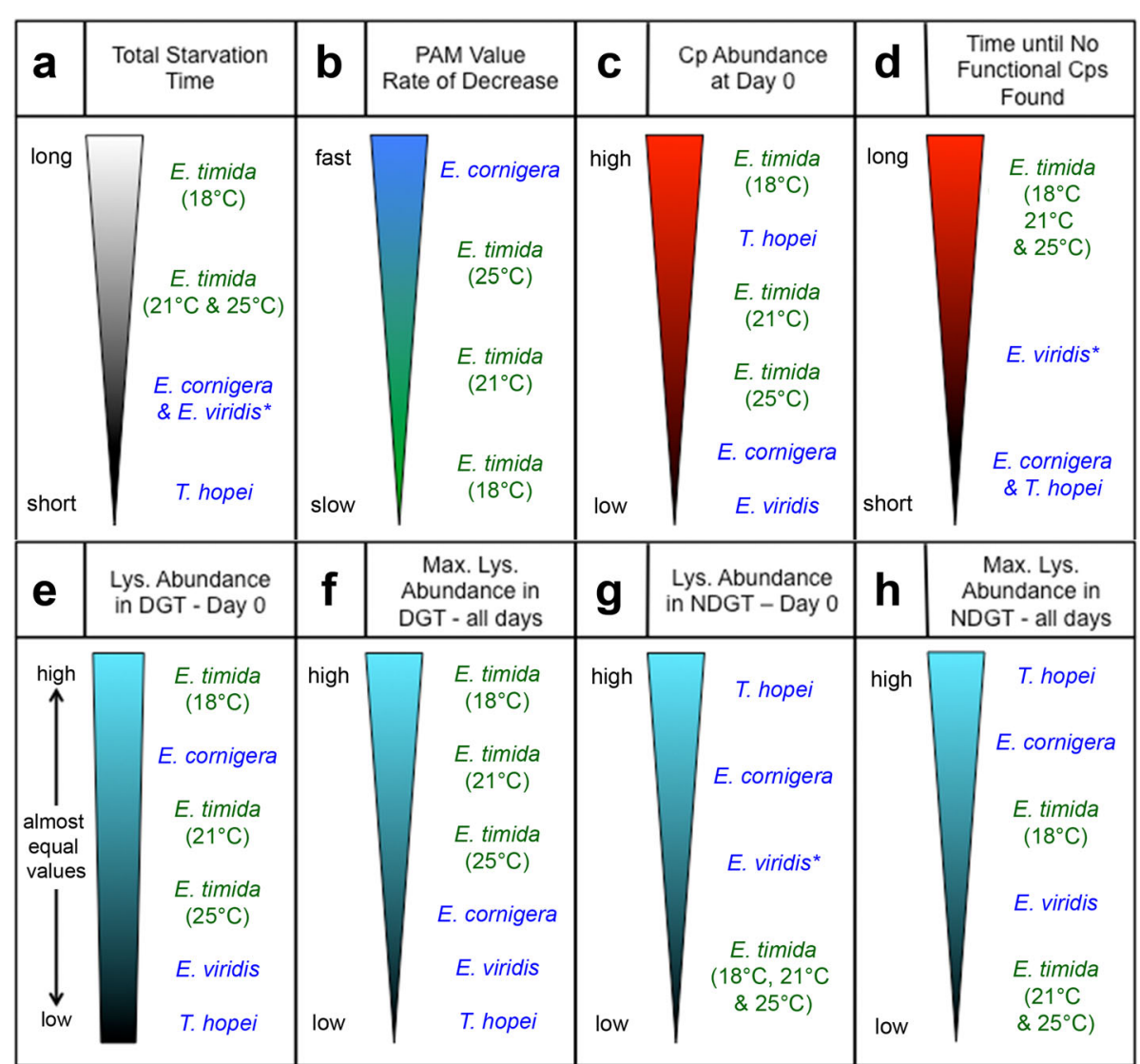

Fig. 7 Overview of the digestive trends in the examined species. To visualize the overall trends observed in each of these populations, for each experiment, the numbers were removed and each population was ranked. The colored triangles represent the quantity of each factor (for example: number of chloroplasts in unstarved animals) from large to small. Each population is listed according to rank. Species written in green are the traditional long-term chloroplast retaining species whereas those in blue are the short-term retaining species. E. viridis is designated in blue with an asterisk because it more closely resembles an StR form in this investigation, but has been classified as LtR in the past. a Total longevity in starvation from a long duration to short. E. timida $18^{\circ} \mathrm{C}$ has the longest longevity in starvation and T. hopei has the shortest. The triangle is colored black and white to represent alive/dead. $\mathbf{b}$ PAM value rate of decrease. E. cornigera have the fastest decrease in photosynthetic efficiency during starvation. The triangle is blue/green because StR is often depicted in blue and LtR in green. c Functional chloroplast abundance in unstarved (Day 0) Slugs. Throughout this investigation, chloroplasts are indicated in red because of their autofluorescence. $\mathbf{d}$ The number of days until functional chloroplasts are no longer observed in the digestive gland. $\mathbf{e}$ Lysosome abundance within the Digestive Gland Tubule (DGT) for unstarved specimens (Day 0). A quadrilateral rather than triangle is drawn because the values are very similar. It is colored blue aligning with the pictures of lysosomes presented in this investigation. $\mathbf{f}$ The maximum lysosome abundance throughout the entire starvation period within the DGT. These maximums occur at different time points for each species. $\mathbf{g}$ Lysosome abundance in Non-Digestive Gland Tissue (NDGT) at Day 0. $\mathbf{h}$ Maximum lysosome abundance in NDGT throughout the stanvation period 
examined metabolic transcription in E. timida and $E$. cornigera, and revealed elevated expression rates of autophagal genes in E. cornigera after 7 days in starvation, which were not present in $E$. timida. Interestingly, $E$. timida and $E$. viridis do not exhibit a visible increase, suggesting the autophagal processes behind their decreased size are not detected using the acridine orange method. Fully understanding the autophagal processes in these species will require further investigations.

The excrement surveys conducted here reveal that $E$. cornigera do not digest all of the chloroplasts they sequester. The chloroplast abundance within the excrement samples deceases throughout the starvation period and since no new chloroplasts were introduced to these animals, it is clear that some chloroplasts were retained for weeks within the digestive gland before finally being excreted. The cause for this delay is unknown, and requires further investigation, but may be due to Reactive Oxygen Species (ROS) buildup around these chloroplasts. ROS accumulation was examined by de Vries et al. [45] in E. cornigera and E. timida, the former showing increases in both hydrogen peroxide $\left(\mathrm{H}_{2} \mathrm{O}_{2}\right)$ and superoxide $\left(\mathrm{O}_{2}^{-}\right)$during starvation. Plastid excretion and autophagy (as seen with the lysosomes in- and outside the digestive gland) by $E$. cornigera may be a response to the buildup of these cytotoxic molecules. Each of the E. timida temperature groups lacked plastids in their excrement, showing that $E$. timida do digest the chloroplasts they sequester. E. timida also lack an increase in ROS during starvation [45], although this was only monitored until the 30-day starvation point, which likely explains the first half of the $E$. timida starvation period, where lysosomal activity is low. Further investigations are needed to confirm if ROS levels increase in E. timida after 30 days, correlating to the lysosomal activity increases observed here. This fundamental difference in the way E. timida and E. cornigera react to their sequestered plastids may be exactly what allows $E$. timida to survive 3-4 times as long as E. cornigera in starvation and ROS could be implicated in the digestive activity differences observed here.

The overall differences observed in each of the species examined here suggest the complexity behind functional kleptoplasty. E. cornigera, T. hopei and E. viridis have all been previously labeled StR forms, which is based on photosynthetic efficiency [17]. Despite this, when another factor is examined, such as functional kleptoplast abundance, this category no longer appropriately groups these organisms. When each of the species examined here is reduced to a trend and compared to the other's trends, it is clear how the LtR, and StR category labels fail to group these organisms in consistent groups. Figure 7 (specifically $\mathrm{C}, \mathrm{E}$ and $\mathrm{H}$ ) compares each species with each of the factors investigated here, to show how this grouping proves inadequate when examining something other than photosynthetic efficiency amongst these animals. Based on this, we therefore suggest that these labels only be used when referring to photosynthetic efficiency amongst sacoglossan slugs. For other factors that have been or may be investigated, such as functional plastid abundance and lysosomal activity, the lack of natural clustering should be kept in mind and these categorical labels avoided.

\section{Conclusions}

Put simply, E. cornigera is not warmed up E. timida incapable of surviving long starvation periods due to higher temperatures. Physiologically, these two species are not the same when it comes to responding to starvation, even under the same temperature conditions, and these dissimilarities require further investigation. Temperature did affect E. timida's photosynthetic efficiency and total starvation time, but could not be correlated to increased digestive rates, autophagy or the decline of functional chloroplasts in these tissues. When the comparison is broadened to include all of the species examined, it is clear that each species reacts to starvation differently, some excreting their chloroplasts - others digesting, some showing signs of autophagy - others not, which defies our ability to assume similarity between sacoglossan species and reveals the complex nature of functional kleptoplasty in these animals.

\section{Additional file}

Additional file 1: Statistical overview. (PDF $3530 \mathrm{~kb}$ )

\section{Abbreviations}

AO: Acridine orange; CLSM: Confocal scanning laser microscope; LtR: Long-term kleptoplast retaining species; PAM: Pulse amplitude modulated fluorometer; PSU: Practical salinity units; ROS: Reactive oxygen species; StR: Short-term kleptoplast retaining species

\section{Acknowledgements}

We would like to thank Dynasty Marine for their help in exporting live animals from Florida to Germany, James Robert Jerschabek Laetz for help with field work, Manuel Ballesteros and Conxita Àvila for their collaboration and collection help in Spain, Pamela Gruver for managing our permits (USA), the entire Keys Marine Lab staff for their help and suggestions, Claudia Müller and Thomas Bartolomaeus for laboratory advice, as well as Michael Middlebrooks and Gregor Christa for collection advice. We also would like to express our sincere thanks to two anonymous reviewers, who helped to improve the first draft.

\section{Funding}

This study was funded by the Deutsche Forschungsgemeinschaft [grant number Wa618-17]. Animal collection was permitted by a Special Activities License granted to Heike Wägele and Elise Laetz (SAL-16-1353C-SR) in Florida, USA and thanks to a permit from the Generalitat de Catalunya granted to the Grup de Recerca en Biologia i Ecologia Bentòniques of the Universitat de Barcelona granted to our collaboration partners.

\section{Availability of data and materials}

No large datasets and/or software were produced for this study, so there is no content here which should be made available. 


\section{Authors' contributions}

EMJL and HW devised the project concept, EMJL developed the method, conducted the lab work, analyzed the results and wrote the first draft. HW helped interpret the results, design the figures and edit the manuscript. Both authors read and approved the final manuscript.

\section{Ethics approval}

All applicable international, national and/or institutional guidelines for the care and use of animals were followed.

\section{Consent for publication}

All authors consent to the publication of this manuscript.

\section{Competing interests}

The authors declare that they have no competing interests.

\section{Publisher's Note}

Springer Nature remains neutral with regard to jurisdictional claims in published maps and institutional affiliations.

\section{Received: 11 October 2017 Accepted: 6 April 2018} Published online: 24 April 2018

\section{References}

1. Trench RK, Greene RW, Bystrom BG. Chloroplasts as functional organelles in animal tissues. J Cell Biol. 1969:42:404-17.

2. Kawaguti S, Yamasu T. Electron microscopy on the symbiosis between an elysioid gastropod and chloroplasts of a green alga. Biol J Okayama Univ. 1965;11:57-65.

3. Taylor DL. Chloroplasts as symbiotic organelles in the digestive gland of Elysia viridis [Gastropoda: opisthobranchia]. J Mar Biol Assoc United Kingdom. 1968:48:1-15.

4. Williams S, Walker D. Mesoherbivore-macroalgal interactions: feeding ecology of sacoglossan sea slugs. Oceanogr Mar Biol An Annu Rev. 1999:37:87-128.

5. Wägele H, Martin W. Endosymbioses in Sacoglossan Seaslugs: plastidbearing animals that keep photosynthetic organelles without borrowing genes. In: Löffelhardt W, editor. Endosymbiosis SE - 14. Vienna: Springer; 2014. p. 291-324.

6. Giménez Casalduero F, Muniain C. The role of kleptoplasts in the survival rates of Elysia timida (Risso, 1818):(Sacoglossa: Opisthobranchia) during periods of food shortage. J Exp Mar Bio Ecol. 2008:357:181-7.

7. Christa G, Zimorski V, Woehle C, Tielens AGM, Wägele H, Martin WF, Gould SB: Plastid-Bearing Sea slugs fix $\mathrm{CO} 2$ in the light but do not require photosynthesis to survive. Proc Biol Sci 2013, 281; doi: https://doi.org/10. 1098/rspb.2013.2493

8. Schmitt V, Händeler K, Gunkel S, Escande M-L, Menzel D, Gould SB, Martin WF, Wägele $\mathrm{H}$. Chloroplast incorporation and long-term photosynthetic performance through the life cycle in laboratory cultures of Elysia timida (Sacoglossa, Heterobranchia). Front Zool. 2014;11:5.

9. Schmitt $\mathrm{V}$, Waegele $\mathrm{H}$. Behavioral adaptations in relation to long-term retention of endosymbiotic chloroplasts in the sea slug Elysia timida. Thalassas. 2011:27:225-38.

10. Marín A, Ros JD. Dynamics of a peculiar plant-herbivore relationship: the photosynthetic ascoglossan Elysia timida and the chlorophycean Acetabularia acetabulum. Mar Biol. 1992;112:677-82.

11. Marín A, Ros J. Ultrastructural and ecological aspects of the development of chloroplast retention in the Sacoglossan gastropod Elysia timida. J Molluscan Stud. 1993:59:95-104.

12. Rahat M. Direct development and symbiotic chloroplasts in Elysia timida (Mollusca: Opisthobranchia). Isr J Zool. 1976;25:186-93.

13. Monselise EB-I, Rahat M. Photobiology of Elysia timida (Mollusca: Opisthobranchia): observations in the sea. Isr J Zool. 1980;29:125-8.

14. Jesus B, Ventura P, Calado G. Behaviour and a functional xanthophyll cycle enhance photo-regulation mechanisms in the solar-powered sea slug Elysia timida (Risso, 1818). J Exp Mar Bio Ecol. 2010;395:98-105.

15. Giménez-Casalduero F, Muniain C. Photosynthetic activity of the solarpowered lagoon mollusc Elysia timida (Risso, 1818) (Opisthobranchia: Sacoglossa). Symbiosis. 2006;41:151-8.
16. Giménez-Casalduero F, Muniain C, González-Wangüemert M, GarroteMoreno A. Elysia timida (Risso, 1818) three decades of research. Anim Biodivers Conserv. 2011;34:217-27.

17. Händeler K, Grzymbowski YP, Krug PJ, Wägele H. Functional chloroplasts in metazoan cells — a unique evolutionary strategy in animal life. Front Zool. 2009;6:28.

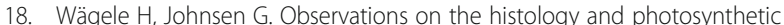
performance of "solar-powered" opisthobranchs (Mollusca, Gastropoda, Opisthobranchia) containing symbiotic chloroplasts or zooxanthellae. Org Divers Evol. 2001;1:193-210.

19. Christa G, Gould SB, Franken J, Vleugels M, Karmeinski D, Händeler K, Martin WF, Wägele H. Functional Kleptoplasty in a Limapontiodean genus: phylogeny, food preferences, and photosynthesis in Costasiella with a focus on C. ocellifera (Gastropoda: Sacoglossa). J Molluscan Stud. 2014;80:499-507.

20. Christa G, Händeler K, Schäberle TF, König GM, Wägele H: Identification of sequestered chloroplasts in photosynthetic and non-photosynthetic sacoglossan sea slugs (Mollusca, Gastropoda). Front Zool 2014, 11; doi: https://doi.org/10.1186/1742.9994.11.15.

21. Curtis NE, Middlebrooks ML, Schwartz JA, Pierce SK. Kleptoplastic sacoglossan species have very different capacities for plastid maintenance despite utilizing the same algal donors. Symbiosis. 2015;65:23-31.

22. Curtis NE, Massey SE, Pierce SK. The symbiotic chloroplasts in the sacoglossan Elysia clarki are from several algal species. Invertebr Biol. 2006;125:336-45.

23. Hirose E. Digestive system of the Sacoglossan Plakobranchus ocellatus (Gastropoda: Opisthobranchia): light- and Electron-microscopic observations with remarks on chloroplast retention. Zool Sci. 2005;22:905-16.

24. Rumpho ME, Pochareddy S, Worful JM, Summer EJ, Bhattacharya D, Pelletreau KN, Tyler MS, Lee J, Manhart JR, Soule KM. Molecular characterization of the Calvin cycle enzyme phosphoribulokinase in the stramenopile alga Vaucheria litorea and the plastid hosting mollusc Elysia chlorotica. Mol Plant. 2009:2:1384-96.

25. Rumpho ME, Summer EJ, Manhart JR. Solar-powered sea slugs. Mollusc/algal chloroplast symbiosis. Plant Physiol. 2000;123:29-38.

26. Green BJ, Li W-Y, Manhart JR, Fox TC, Summer EJ, Kennedy RA, Pierce SK, Rumpho ME. Mollusc-algal chloroplast endosymbiosis. Photosynthesis, thylakoid protein maintenance, and chloroplast gene expression continue for many months in the absence of the algal nucleus. Plant Physiol. 2000;124:331-42.

27. Mondy WL, Pierce SK. Apoptotic-like morphology is associated with annual synchronized death in kleptoplastic sea slugs (Elysia chlorotica). Invertebr Biol. 2003;122:126-37.

28. Pierce SK, Fang X, Schwartz JA, Jiang X, Zhao W, Curtis NE, Kocot KM, Yang $B$, Wang J. Transcriptomic evidence for the expression of horizontally transferred algal nuclear genes in the Photosynthetic Sea slug, Elysia chlorotica. Mol Biol Evol. 2012;29:1545-56.

29. Christa G, Wescott L, Schäberle TF, König GM, Wägele $H$. What remains after 2 months of starvation? Analysis of sequestered algae in a photosynthetic slug, Plakobranchus ocellatus (Sacoglossa, Opisthobranchia), by barcoding. Planta. 2013:237:559-72

30. Maeda T, Hirose E, Chikaraishi Y, Kawato M, Takishita K, Yoshida T, Verbruggen H, Tanaka J, Shimamura S, Takaki Y: Algivore or phototroph? Plakobranchus ocellatus (Gastropoda) continuously acquires kleptoplasts and nutrition from multiple algal species in nature. PLoS One 2012, 7; doi: https://doi.org/10.1371/journal.pone.0042024.

31. Evertsen J, Burghardt I, Johnsen G, Wägele H. Retention of functional chloroplasts in some sacoglossans from the indo-Pacific and Mediterranean. Mar Biol. 2007;151:2159-66.

32. Pierce SK, Curtis NE, Massey SE, Bass AL, Karl SA, Finney CM. A morphological and molecular comparison between Elysia crispata and a new species of kleptoplastic sacoglossan sea slug (Gastropoda: Opisthobranchia) from the Florida keys, USA. Molluscan Res. 2006;26:23-38.

33. Christa G, Händeler K, Kück P, Vleugels M, Franken J, Karmeinski D, Wägele $H$. Phylogenetic evidence for multiple independent origins of functional kleptoplasty in Sacoglossa (Heterobranchia, Gastropoda). Org Divers Evol. 2014;15:23-36.

34. Krug PJ, Vendetti JE, Valdes A. Molecular and morphological systematics of Elysia Risso, 1818 (Heterobranchia: Sacoglossa) from the Caribbean region. Zootaxa. 2016:4148(1):137.

35. Hinde R, Smith DC. Persistence of functional chloroplasts in Elysia viridis (Opisthobranchia, Sacoglossa). Nature. 1972;239:30-1.

36. Teugels B, Bouillon S, Veuger B, Middelburg JJ, Koedam N: Kleptoplasts mediate nitrogen acquisition in the sea slug Elysia viridis. Aquat Biol 2008, 4; doi: https://doi.org/10.3354/ab00092. 
37. Laetz EMJ, Rühr PT, Bartolomaeus T, Preisfeld A, Wägele H. Examining the retention of functional kleptoplasts and digestive activity in sacoglossan sea slugs. Org Divers Evol. 2016;17:87-99.

38. Trench RK, Boyle JE, Smith DC. The association between chloroplasts of Codium fragile and the Mollusc Elysia viridis. III. Movement of photosynthetically fixed $\mathrm{C}^{14}$ in tissues of intact Living $E$. viridis and in Tridachia crispata. Proc R Soc London B Biol Sci. 1974;185:453-64.

39. Trench RK, Boyle JE, Smith DC. The association between chloroplasts of Codium fragile and the mollusc Elysia viridis. II. Chloroplast ultrastructure and photosynthetic carbon fixation in E. viridis. Proc R Soc London B Biol Sci. 1973;184:63-81.

40. Evertsen J, Johnsen G. In vivo and in vitro differences in chloroplast functionality in the two North Atlantic sacoglossans (Gastropoda, Opisthobranchia) Placida dendritica and Elysia viridis. Mar Biol. 2009;156:847-59.

41. Wägele H, Stemmer K, Burghardt I, Händeler K. Two new sacoglossan sea slug species ( Opisthobranchia, Gastropoda ). Zootaxa. 2010;28:1-28.

42. Krug PJ, Händeler K, Vendetti J. Genes, morphology, development and photosynthetic ability support the resurrection of Elysia cornigera (Heterobranchia: Plakobranchoidea) as distinct from the 'solar-powered' sea slug, E. timida. Invertebr Syst. 2012;25:477-89.

43. Carmona L, Malaquias MAE, Gosliner TM, Pola M, Cervera JL. Amphi-Atlantic distributions and cryptic species in sacoglossan sea slugs. J Molluscan Stud. 2011;77:401-12.

44. Ortea J, Moro L, Espinosa J. Nuevos datos sobre el género Elysia, 1818 (Opisthobranchia: Sacoglossa) en el Atlántico. Rev la Acad Canar Ciencias= Folia Canar Acad Sci. 1997:9:141-55.

45. de Vries J, Woehle C, Christa G, Wägele H, Tielens AGM, Jahns P, Gould SB. Proc Comparison of sister species identifies factors underpinning plastid compatibility in green sea slugs. R Soc London B Biol Sci. 2015;282 https://doi.org/10.1098/rspb.2014.2519.

46. de Vries J, Christa G, Gould SB. Plastid survival in the cytosol of animal cells. Trends Plant Sci. 2014;19:347-50.

47. Soto IM, Muller Karger FE, Hallock P, Hu C. Sea surface temperature variability in the Florida keys and its relationship to coral cover. J Mar Biol. 2011;2011 https://doi.org/10.1155/2011/981723.

48. Marullo S, Nardelli BB, Guarracino M, Santoleri R. Observing the Mediterranean Sea from space: 21 years of pathfinder-AVHRR Sea surface temperatures (1985 to 2005): re-analysis and validation. Ocean Sci. 2007;3:299-310.

49. Laetz EMJ, Moris VC, Moritz L, Haubrich AN, Wägele H. Photosynthate accumulation in solar-powered sea slugs - starving slugs survive due to accumulated starch reserves. Front Zool. 2017;14:4. https://doi.org/10.1186/ s12983-016-0186-5.

50. Wägele H, Deusch O, Händeler K, Martin R, Schmitt V, Christa G, Pinzger B, Gould SB, Dagan T, Klussmann-Kolb A, Martin W. Transcriptomic evidence that longevity of acquired plastids in the photosynthetic slugs Elysia timida and Plakobranchus ocellatus does not entail lateral transfer of algal nuclear genes. Mol Biol Evol. 2011;28:699-706.

51. Rauch C, de Vries J, Rommel S, Rose LE, Woehle C, Christa G, Laetz EM, Wägele $H$, Tielens AGM, Nickelsen J. Why it is time to look beyond algal genes in photosynthetic slugs. Genome Biol Evol. 2015;7:2602-7.

52. Baumgartner FA, Pavia H, Toth GB. Acquired Phototrophy through retention of functional chloroplasts increases growth efficiency of the sea slug Elysia viridis. PLoS One. 2015; https://doi.org/10.1371/journal.pone.0120874.

53. Ventura P, Calado G, Jesus B. Photosynthetic efficiency and kleptoplast pigment diversity in the sea slug Thuridilla hopei (Vérany, 1853). J Exp Mar Bio Ecol. 2013;441:105-9.

54. Martin R, Walther P, Tomaschko K-H. Variable retention of kleptoplast membranes in cells of sacoglossan sea slugs: plastids with extended, shortened and non-retained durations. Zoomorphology. 2015;134:523-9.

Ready to submit your research? Choose BMC and benefit from:

- fast, convenient online submission

- thorough peer review by experienced researchers in your field

- rapid publication on acceptance

- support for research data, including large and complex data types

- gold Open Access which fosters wider collaboration and increased citations

- maximum visibility for your research: over $100 \mathrm{M}$ website views per year

At BMC, research is always in progress.

Learn more biomedcentral.com/submissions 